We have unquestionable evidence that complete combustion of their vapor has at last been attained. These methods open the way to an unlimited amount of further experimentation, and promise to afford results upon which interesting theoretical considerations may be founded.

It is a pleasure to acknowledge my thanks to my several assistants, Professor A. B. Lamb, and Drs. L. J. Henderson, G. S. Forbes, H. L. Frevert, A. W. Rowe, R. H. Jesse, Jr., and L. L. Burgess for their expert assistance in these protracted and often tiresome researches, as well as to express my obligations to the Cyrus M. Warren Fund of Harvard University, the Rumford Fund of the American Academy of Arts and Science and especially to the Carnegie Institution of Washington, for generous pecuniary help in the prosecution of the work.

Before closing let me review briefly the recent advances in thermochemistry which I have attempted to enumerate. In the first place, the thermometric scale has been far more definitely fixed than it was thirty years ago. In the next place, the determination of specific heat and therefore of heat capacity has been put upon a scientific basis and its precise treatment in the calculation of thermochemical results has been pointed out. In the next place the most serious correction for all thermochemical results in the past, namely the cooling correction, has been entirely obviated by the use of the method preventing loss of any heat from the calorimeter by enclosing the latter in a jacket of similarly changing temperature. Again the necessity for more active agitation of the contents of the calorimeter has been demonstrated, and the necessity of the use of very pure materials has been put beyond question. In every case the effort has been made to insure the completeness of the reaction and to correct for any side reactions which may take place at the same time, so that the final results may represent truly the data sought. In short the effort has been made to apply to these fundamental figures concerning chemical energetics the same kind of precision which has recently been attempted in the revision of atomic weights; and although on account of the greater complexity of the problem the percentage accuracy thus far reached has probably not equaled that in the case of atomic weights, one cannot help thinking that the proportional gain over the previous investigations is perhaps as great in this case as in the other.

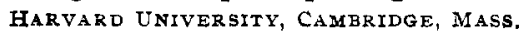

\title{
NOTE.
}

The Nomenclature of $\mathrm{H}_{2} \mathrm{~S}$.- Although it takes a great deal of time to substitute a new name for an old one in a science, it seems as if efforts should be made from time to time to introduce uniformity or simplicity where possible. The names hydrogen sulphide and sulphuretted hydrogen, besides being cumbersome, give no suggestion of the acidic nature of $\mathrm{H}_{2} \mathrm{~S}$ and it seems as if they should be dropped. Following German, French or Spanish usage it might be designated sulphydric acid, but the English usage would be hydrosulphuric acid, comparable to other binary acids like hydrochloric, etc. I do not see any good reason, however, why this could not be shortened simply to hydrosulphic, or in the 
latest spelling, hydrosulfic acid. Possibly the suggestion may start the uniform adoption of the simplest term.

ROGER C. WELLS.

\section{REVIEW. \\ RECENT WORK IN INORGANIC CHEMISTRY.}

BY JAS. LEWIS HOWE.

Received November 4, Igog.

New Elements.-On the occasion of the completion of the twenty-fifth year of the professorship of Dr. Sakurai at the University of Tokio, a volume of chemical papers by his students was published. Among these were two preliminary communications by Ogawa $(J$. Coll. of Sci., Imp. Univ., Tokyo, 25, I5, I6) on two new elements discovered in residues from thorianite and molybdenite on which he had worked under Sir William Ramsay. One element, for which Ramsay suggested the name nipponium, has an equivalent weight of about 50 and from its properties seems to be the missing element, of atomic weight ıoo, standing between molybdenum and ruthenium ("eka-manganese"). The other element is somewhat similar in its properties and may have an atomic weight of 150 , being a higher member of the manganese group. Skrabal and Artmann (Chem.Ztg., 33, I43) consider that this second element may be identical with one met by them in the analysis of ferrovanadium, and possibly the same noticed by Boucher and by Ruddock (Chem. News, 76, 99, I 8 ) in pig iron and steel.

New Compounds, Group II.-Marsh and Struthers (Proc. Chem. Soc., $24,266)$ find that in cold aqueous potassium hydroxide ketones are quantitatively precipitated by mercuric iodide, the hydrogen on the carbon atoms adjacent to the carbonyl group being completely replaced by $\mathrm{Hg}^{\prime \prime} \mathrm{I}$ or $\mathrm{Hg}$. Thus with acetone the compound $\mathrm{CO}: \mathrm{C}_{2}(\mathrm{HgI})_{2} \mathrm{Hg}$ is formed; with diethylketone, $\left(\mathrm{CH}_{3} \cdot \mathrm{C}(\mathrm{HgI})_{2}\right)_{2} \mathrm{CO}$. By the action of mercuric sulphate on carbon disulphide, Estrup (Z. anorg. Chem., 62, 168) has prepared a mixed thiobasic sulphate of mercury, $4 \mathrm{HgO} .2 \mathrm{HgS} .3 \mathrm{SO}_{3}$. ${ }_{4} \mathrm{H}_{2} \mathrm{O}$, in brilliant white crystals, which appears to be a definite chemical individual.

Group III.-When $\mathrm{BCl}_{3}$ is led in a current of hydrogen over finely divided chromium (du Jassonneix, Ann. chim. phys. [8], I7, I45) at I IOO ${ }^{\circ} \mathrm{CrB}$ appears to be formed. If this is further heated in an electric furnace with iron and boron, complex alloys, but no definite compound, are formed. Aluminium decomposes the $\mathrm{CrB}$ with formation of $\mathrm{AlB}_{2}$. This last, described by Deville and Wöhler under the name of graphitic boron, becomes changed by heating with an excess of boron into octahedra, which the author calls diamond-like boron. If boron and aluminium are heated with carbon in the electric furnace, transparent hexagonal plates are formed which appear to be a solid solution of $\mathrm{AlB}_{2}$ and $\mathrm{Al}_{4} \mathrm{C}_{3}$. Below $1420^{\circ}$ platinum does not take up over $4^{1} / 2$ per cent. of boron. Boron is insoluble in copper, silver and tin. Sir William Crookes has continued his work on scandium from wiikite $(Z$. anorg. Chem., 6r, 349) preparing the fluoride, $\mathrm{ScF}_{3}$, and a number of salts of organic acids, most of which are basic. Crookes suggests that since $B$ II $\times$ I $6=176$, Sc $44.1 \times_{4}=176.4, Y 89 \times 2=178$, and $\mathrm{Yb} \mathrm{I}_{73} \times_{\mathrm{I}}=173$, and the variations from the number 176 may be due to uncertain atomic 